\title{
Application of PCR in Food Biochemistry
}

\author{
Milica Pavlićević and Biljana Vucelić-Radović
}

\begin{abstract}
For detection of genetically modified organisms, several different methodologies could be employed. Different types of quantitative PCR (qPCR) are used for tracing changes of DNA and/or RNA differing in type of compound and mechanism used for detection (intercalating dyes, primers and probes). Different types of PCR were developed based on specific part of DNA being investigated. Besides PCR methods, several novel methods are employed. Next generation sequencing is used for obtaining information about localization and sequence of insert and its flaking regions. Microarray technology allows for multiple DNAs to be analyzed simultaneously on the chip. Decision-support system that detect and quantify GMO based on the $\mathrm{Ct}$ and Tm values and the LOD and LOQ is used in so-called matrix based methods. In so-called "food forensics" parameters like protected designation of origin (PDO) and protected geographic indication (PGI) that serve as an indication of food quality are being determined. In PGI determination several methods can be employed depending from type of molecule or parameters being analyzed, e.g. mass spectrometry for determining isotope ratio, spectroscopy or chromatography
\end{abstract}

\section{How to cite this book chapter:}

Pavlićević, M. and Vucelić-Radović, B. 2019. Application of PCR in Food Biochemistry. In: Vucelić Radović, B., Lazić, D. and Nikšić, M. (eds.) Application of Molecular Methods and Raman Microscopy/Spectroscopy in Agricultural Sciences and Food Technology, Pp. 97-117. London: Ubiquity Press. DOI: https://doi.org/10.5334/ bbj.g. License: CC-BY 4.0 
for monitoring changes in lipid profiles etc. For determination of PDO, PCR methods that trace unique sequences, like single nucleotide polymorphisms (SNPs), restriction fragment length polymorphisms (RFLPs), amplified fragment length polymorphisms (AFLP), simple sequence length polymorphisms (SSLPs) are used. Novel method called DNA barcoding uses markers (short sequence complementary to target region) that can identify variation among cultivars. Today, in food forensics genomics, proteomics and metabolomics for determining authenticity are used. Both for DNA and RNA extraction, due to "matrix effect" choice of extraction method is of crucial importance for obtaining high amount of non-degraded pure nucleic acid. Thus, although both extraction of DNA and RNA consist of same basic steps (homogenization, lysis and extraction, purification (precipitation or binding), elution or resolubilization), lysis and extraction step will have the most influence on quality of isolated nucleic acid. During DNA extraction it is possible to use either kits (that are developed for specific purpose) or "traditional methods" were organic solvents are used for extraction. Today, for extraction of RNA mostly kits developed for RNA extraction from specific organisms and/or tissue are used. Since RNA is chemically more unstable than DNA it can easily be degraded during sampling and homogenization. For monitoring gene expression, Real Time PCR is used. Design of primer is possible in on-line free software such as Primer3 and Primer3Plus from NCBI or in software that are supplied with Real time PCR apparatus. Analysis of primers (possibility of formation of secondary structure, like hairpins and/or primer-dimmers) can be done in software like Vector NTI and MP primer.

\section{1 "Food forensics"}

Since in recent years safety and quality of food has become hot topic, determination of protected designation of origin (PDO) and protected geographic indication (PGI) as parameters for food quality has become imperative.

In determination of geographical origin of food, several methodologies classified by type of molecule being analyzed and parameters that are monitored have been employed (Luykx et al. 2008). In mass spectrometry methods composition of sample is determined by ionization of sample and subsequent measurement of ions $\mathrm{m} / \mathrm{z}$ ratio and production of mass spectrum. So-called isotope ratio mass spectrometry has successfully being employed in authentication of food of animal origin by examining ratio of isotopes (Vinci et al. 2013). Isotopes ratio depends of several factors, such as animal diet, use of fertilizers etc., but among them geographical factors (such as soil composition, altitude etc.) play crucial role (Luykx et al. 2008). Spectroscopic methods such as infrared spectroscopy, can be used either to monitor production process like ripening in cheeses (Woodcock et al. 2008) or for determining authenticity by measuring changes in, for example, fatty acids profile, sterol and/or phenolic composition, 
volatile compounds, etc. Chromatographic methods, such as gas chromatography or high pressure liquid chromatography, can be used for determining authenticity of plant oils by, for example, determining its diacylglycerol and triacylglycerol profiles (Cserháti et al. 2008).

Food forensics employs genomics, proteomics and metabolomics for determining authenticity (Primrose et al. 2010). Mayor advantage of this integrative approach is that results of each individual method are verified in subsequent steps and limitations of particular technique are overcome by employing several levels of analysis.

PCR methods that are used for food authentication are based on tracing unique sequences (so-called DNA fingerprinting). Such methods include single nucleotide polymorphisms (SNPs), restriction fragment length polymorphisms (RFLPs), amplified fragment length polymorphisms (AFLP), simple sequence length polymorphisms (SSLPs) and, the use of real-time PCR and heteroduplex analysis (Primrose et al. 2010, Agrimonti et al. 2011). All of these methods detect small variation in base-pair sequence ("polymorphism").

In new approach, called DNA barcoding, markers (short sequence complementary to target region) are used to indentify not only species, but variation among cultivars (Galimberti et al. 2013). Although DNA barcoding is rapid, cheap and sensitive method, applying this technique on highly processed food can be unreliable, due to loss of DNA integrity (Galimberti et al. 2013).

Nowdays, for determination of protected designation of origin, genomic methods are combined with hysic-chemical detection. For example, Ganopoulos et al. (2011) used detection of microsatellite sequences with subsequent analysis by capillary electrophoresis and high resolution melting in determination of protected designation of origin of sweet cherry products.

\section{Detection of GMO in food}

Detection of genetically modified organisms in food could be achieved by employing several methods. Generally, these methods can be divided based on in what type of molecule changes is being detected. For tracing changes on protein level, enzyme-linked immunosorbent assay (ELISA), lateral flow sticks, Western blot and 2D electrophoresis are used. For tracing changes on DNA and/or RNA level, PCR methods are used. Broadly, PCR methods can be divided depending on their application and mechanism which is used for detection.

In so-called quantitative PCR (qPCR) that is used for screening of GMO, three types of chemistries are used. Intercalating dyes are molecules which aromatic ring(s) which are able to insert themselves between bases in DNA (usually in major groove). PCR methods using intercalating dyes (such as SYBR Green) are the cheapest, but sensitivity with single stranded DNA is low and in higher concentration they inhibit PCR reaction (Gasparic et al., 2010). There 
are several different chemistries currently employed in primer-based PCR. Their basic principle is the same: fluorescent dye (fluorofore) is attached to one end of primer and fluorescent signal is changed (decreased or increased) following annealing and extension step. However, crucial differences in these methods are in additional presence of synthetic bases (like in Plexor primers) or quenchers on the other end of primers (like in AmpiFluor primers). Such modifications enhance sensitivity and specificity of PCR reactions. Although, primer-based chemistry is more expensive than chemistry employing intercalating dyes, it is more sensitive and with higher specificity compared to SYBR Green PCR and it also gives possibility of multiplex PCR (when 4 different fluorofores, each specific to particular base, are used). However, primer-dimers and unspesific amplicons will also be detected (Gasparic et al. 2010). In probebased chemistries (such as TaqMan) additional nucleotide sequence complementary to target sequence between primers (called probe) is used. Probe is marked with quencher at one end and fluorofore at the other end. After the extension step, quencher and fluorofore are realeased and absorbance is increased. TaqMan probe PCR is more expensive than SYBR Green PCR and primer-based PCR, but it has higher dynamic range, amplification efficiency and repeatability (Gasparic et al. 2010). Minor groove binding TaqMan probe is a variation of TaqMan PCR where TaqMan probe is bound to minor groove of DNA which in turn makes DNA-probe complex more stable and enhances specificity. Additional probe designs such as locked nucleic acid probe (LNA), cycling probe technology (CPT), and molecular beacons are also used.

The gene-specific PCR is more rigorous and more sensitive approach compared to real time PCR (Wen-Tao et al. 2009). It allows for multiplication of specific gene that codes for protein that can alter properties of particular cultivar or food product. For example, p35 gene in tomato codes for inhibitor of caspases, inhibiting cell death and providing for protection against diseases (Lincoln et al, 2002).

Target for construct-specific PCR is junction between two elements in DNA, usually between promotor and transgene. Therefore, positive signal will be present only in GMO material. However, if the same "foreign DNA" is present in different samples, difference in samples can't be detected (Wen-Tao et al. 2009). This type of PCR can be used, for example, for detection of $B t$ gene (coding for cytotoxin Cry A) in Roundup crops (Mesnage et al. 2013).

Since event-specific PCR targets locus between recipient and inserted DNA, it is even more specific and robust than construct-specific PCR (Randhawa et al. 2016). Event-specific PCR is often used for detection of Roundup Ready soybean and Bt-176 "Maximizer" maize in food (Berdal et al. 2001) even in highly-processed foodstuffs (Tengel et al. 2001).

To obtain information about localization and sequence of insert and its flaking regions, next generation sequencing is employed. Mayor difference between "classical" sequencing (by capillary electrophoresis) and next generation sequencing is that instead sequencing single DNA fragment in next 


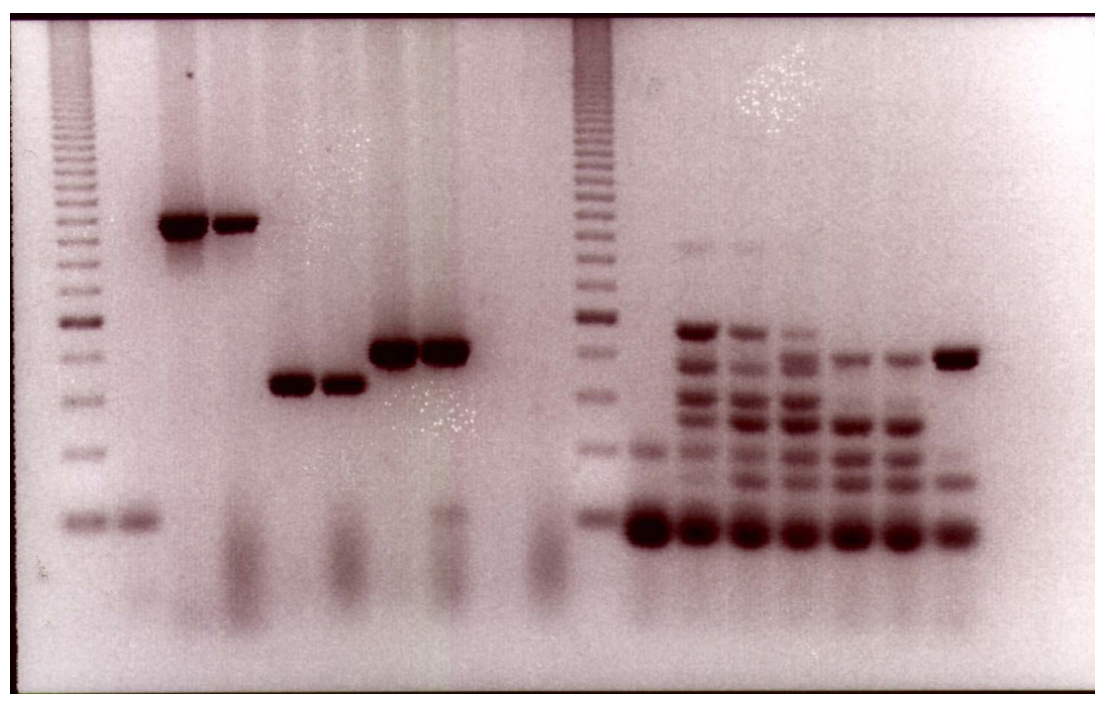

Figure 1: From left to right: lanes 1 and 11. 50-bp molecular mass markers; 2. PCR blank; 3 and 4. PCR products obtained by amplifying, in the presence of primer pairs (441 bp) for detecting DNA from Roundup Ready soybean; 5 and 6. Roundup Ready soybean (156 bp); 7 and 8. soybean lectin (210 bp); lanes 12-18. multiplex PCR products obtained by amplifying, in the presence of seven primer pairs for the simultaneous screening of endogenous genes of soybean and maize and five recombinant DNA constructs of genetically modified crops: Roundup Ready soybean and Bt11, Bt176, GA21, and MON810 lines of maize.

generation sequencing a large number of DNA fragments are sequenced simultaneously. Next generation sequencing coupled with site-finding PCR allowed detection of vip3Aa20 gene (coding for insecticidal protein) in MIR162 maize (Randhawa et al. 2016).

In microarray technology, DNA is attached to surface in form of microscopic spots. The biggest advantages of microarray technology are high sensitivity and high throughout (Berdal et al. 2001). Since different sequences can be analyzed simultaneously, there are different variations of microarray methodology (multiplex microarray, ligation detection reaction coupled with universal array technology, event-specific microarray, etc). For example, an event-specific DNA microarray was used to detect multiple GM events in processed food (soybean, maize, canola and cotton) (Kim et al. 2010).

Matrix based methods, like "Combinatory qPCR SYBR Green screening", use decision-support system that detect and quantify GMO based on 4 values: the $\mathrm{Ct}$ and Tm values and the LOD and LOQ (Van der Bulcke et al. 2010). Ct or "threshold cycle" represents a level above which fluorescence of sample exceeds 
background fluorescence. Ct value is inversely proportional to amount of DNA. $\mathrm{Tm}$ is a melting temperature. LOD represents limit of detection, while LOQ represents limit of quantification.

In contrast to previously mention methods, loop-mediated isothermal amplification (LAMP) is performed at constant temperature. Characteristic of LAMP is that 4 different primers are used for detection of 6 distinct regions on the target gene, with additional loop primers that accelerate reaction. Presence of multiple primers enhances sensitivity. During last few years, real-time LAMP assays for detection of two major commercialized Bt cotton events, MON531 and MON15985 were developed (Randhawa et al. 2016).

Key factor determining not only method for detection of GMO, but also for extraction is quality of DNA. During technological processing, quality, quantity and purity of DNA are all affected. For example, at lower $\mathrm{pH}(\mathrm{pH} 3-4)$, glycosilic bonds between base and ribose are broken (Gryson et al. 2010). At $\mathrm{pH}$ above $\mathrm{pH}$ 8 , the tautomeric state of the bases is affected. These tautomers can form nonstandard base pairs that fit into the double helix and can cause the introduction of mutations during DNA replication. High temperature causes depurination and deamination which lead to degradation of DNA (Gryson et al. 2010). The effect of both temperature and water pressure during autoclaving has stronger degrading effect than cooking. For example, after autoclaving of soybeans at $121^{\circ} \mathrm{C}$ for 15 min only DNA fragments shorter than $295 \mathrm{bp}$ are obtained (Ogasawara et al. 2003). Baking experiments at different temperature showed that baking reduces the size of the extracted DNA (Hrncirova et al. 2008).

\subsection{Extraction of DNA from food}

\subsubsection{Introduction:}

Nowadays, there are a variety of different methods for extraction of DNA from food sources that are being employed. In order to account for so-called "matrix effect" choice of extraction method largely depends on type ofsample that is being analyzed and degree of processing. However, goal of each of these methods is to gain high amount of non-degraded pure DNA of sufficient length. These requirements for intact DNA of substantial size stem from the fact that isolated DNA usually needs to be amplified for further experiments.

Although different in types of chemicals that are used and the mechanism by which DNA is isolated, each protocol for extraction of DNA from food samples consists of several basic steps:

1. Homogenization

2. Lysis and extraction

3. Purification (precipitation or binding)

4. Elution or resolubilization 
Homogenization step serves for two purposes: to disrupt cells membranes (and/ or cells walls) and to obtain the homogeneous, representative sample. Although different methods of homogenization exist (mortar and pestle, bead mills, rotor-stator homogenizator etc.) all of them use mechanical force. The impact of homogenization method on quality of obtained DNA is scarcely known, but several researches suggest (Colatat, Miller et al. 1999) that method of homogenization affects yield and purity as well as the fragment size of isolated DNA. In terms of yield and purity of DNA, homogenization with bead mill was found to be the best method, but rotor-stator homogenization gave the best results when it comes to fragment length. Food samples that contain large amount of compounds that can act as PCR inhibitors (lipids, phenolic compounds, polysaccharides etc. (Wilson et al. 1997) require pre-treatment (Terry et al. 2002). Methods for elimination of such contaminants depend on contaminant type (Terry et al. 2002). For example, lipids could be removed by hexane.

In lysis and extraction step cell wall or/and cell membrane that were disrupted in previous step are now being dissolved and cell releases its content, thus facilitating extraction of DNA from nucleus. For this purpose, lysis buffers are used and although their composition might vary depending on extraction method, they must contain following components: detergents (compounds able to remove/solubilize membrane lipids), RNAses (enzymes that degrade RNA) and proteinases that denaturize proteins. Often lysis buffer contains salt (for disturbing ionic bonds between proteins, mainly histones, and DNA) and chelating agent (that prevents degradation of DNA by binding ions like $\mathrm{Mg}^{2+}$ that serve as cofactors for DNAses). Generally, new methods for DNA extraction are mainly based on use of so-called kits. Two major types of kits used for extraction of DNA from food samples are: silica-based kits (like Wizard, NucleoSpin Food, QIAamp DNA Stool (Turci et al. 2010, Pirondini et al. 2010, Tung Nguyen et al. 2009) and kits that contain magnetic beads (like PrepFiler ${ }^{\text {Tm }}$ Forensic DNA Extraction Kit). In "traditional methods" organic solvents (e.g. phenol, chloroform, ethanol etc.) are used for extraction. Of these methods, SDS (sodium dodecyl sulfate) extraction and CTAB (cetyl trimethylammonium bromide) extraction are still used and modified today. Both of these methods give a high amount of DNA (Turci et al. 2010) and use relatively cheap chemicals, which are the main reasons behind their popularity. However, by comparing SDS and CTAB extraction, it could be concluded that CTAB method gives high yield even with thermally or chemically processed samples (such as cheese or cooking cream) while the same is not true for SDS extraction (Turci et al. 2010, Pirondini et al. 2010, Tung Nguyen et al. 2009). Also, with such samples that contain a high number of PCR inhibitors, SDS method gives a fragmented DNA (Turci et al. 2010, Pirondini et al. 2010). However, since modification of original CTAB procedure often involve transferring of sample from one tube to another, that can cause loss of the sample and increase risk of contamination. Also, both SDS and CTAB methods are time-consuming. Since CTAB method employs use of aggressive chemicals it gives DNA of lower quality 
compared with some novel methods such as Wizard (Turci et al. 2010). Mayor advantage of new methods is that they are fast. However, since most of the kits were developed for specific purpose, they don't give DNA of substantial yield or good quality with samples with higher degree of processing or with samples that greatly differ in their chemical composition from samples for which kit was developed. For example, with fresh and processed tomato products, NucleoSpin Food kit gave highest yield of all examined kits, but DNA was more degraded when compared to QIAamp DNA Stool and Wizard kits. Additional problem with usage of kits for DNA extraction is a high cost of chemicals that are needed for binding and purification of DNA.

During purification, DNA is separated from contaminants in solution. With traditional methods, this is done by precipitation of DNA. However, these methods differ in their ability to remove particular types of contaminants. Relatively high concentration of salt in $\mathrm{CTAB}$ buffer prevents co-precipitation of polysaccharides with DNA. However, CTAB is not as efficient as SDS in denaturating proteins and therefore proteins can remain as contaminants in precipitate. Both silica-based kits and kits with magnetic beads use negative charge of DNA for purification. Mechanism of purification of DNA by silica-based kits is not yet fully understood, but it is considered that chaotropic salts present in buffer are involved in formation of salt bridges between silica membrane and DNA. In complex mixtures such as food this can present a problem, since different compounds with same charge as DNA might remain in solution. Therefore, they will bind with DNA to the column and co-elute. Kits with magnetic beads are more successful in binding DNA, since negatively charged DNA is adsorbed on positively charged magnetic beads.

Since change in $\mathrm{pH}$ and/or ionic force is usually necessary for elution from membranes and columns, this step is also very sensitive, because such changes can fragment DNA. With traditional methods, resolubilization of precipitate might be an issue because usage of organic solvents might cause changes in DNA structure that can interfere with resolubilization of precipitate.

Since economics also plays significant part in choosing preferred method, a new approach called "fuzzy logic" is introduced in evaluation of methods for extracting DNA from food samples. That approach takes into account complexity of individual sample and ranks method not only by yield and quality of isolated DNA, but also by its cost.

Purity and concentration of isolated DNA can both be assessed using spectrometry to measure $A_{260} / A_{280}$ ratio. Absorbance at $260 \mathrm{~nm}$ steams from aromatic rings in nitric bases in DNA, while absorbance at $280 \mathrm{~nm}$ is caused by presence of aromatic amino acids. Thus, this ratio is indicator of protein contamination. DNA with value higher than 1.8 for $\mathrm{A}_{260} / \mathrm{A}_{280}$ ratio is generally considered as pure.

Quality of isolated DNA is determined by agarose electrophoresis and/or number of successful PCR reactions. 


\subsubsection{Materials, Methods and Notes}

A. DNA extraction from milk using CTAB method (according to Corbispier et al. (2007))

\section{Reagents needed:}

CTAB extraction buffer (20 g of cetyl trimethylammonium bromide was dissolved in $1 \mathrm{l}$ of $0.1 \mathrm{M}$ Tris- $\mathrm{HCl}$ buffer $\mathrm{pH} 8$ containing $1.4 \mathrm{M} \mathrm{NaCl}$ and $20 \mathrm{mM}$ EDTA)

CTAB precipitation buffer ( $5 \mathrm{~g}$ of trimethylammonium bromide was dissolved in 11 of $40 \mathrm{mM} \mathrm{NaCl}$ )

RNAse A solution (100 mg/mL)

Proteinase K solution $(20 \mathrm{mg} / \mathrm{ml})$

$1.2 \mathrm{M} \mathrm{NaCl}$

Chloroform

Ethanol (absolute and $70 \%(\mathrm{v} / \mathrm{v})$ )

Nuclease free water

\section{Procedure:}

1. Incubate $100 \mu \mathrm{l}$ of sample with $300 \mu \mathrm{l}$ of nuclease-free water, $700 \mu \mathrm{l}$ of CTAB extraction buffer and $5 \mu \mathrm{l}$ of RNase A solution at $65^{\circ} \mathrm{C}$ for $15 \mathrm{~min}$.

2. Add $20 \mu \mathrm{l}$ of proteinase $\mathrm{K}$ solution and incubate for $15 \mathrm{~min}$ at $65^{\circ} \mathrm{C}$.

3. Centrifuge for $10 \mathrm{~min}$ at $12000 \mathrm{~g}$.

4. Transffer supernatant to a new tube and mix with $500 \mu \mathrm{l}$ of chloroform

5. Transffer aqueous phase $(700 \mu \mathrm{l})$ to new tube and mix with $700 \mu \mathrm{l}$ of chloroform

6. Centrifuged for $5 \mathrm{~min}$ at $12000 \mathrm{~g}$

7. Transffer suppernatat in new tube and incubate with with a double volume of CTAB precipitation buffer for $1 \mathrm{~h}$ at room temperature

8. Centrifuge for $15 \mathrm{~min}$ at $12000 \mathrm{~g}$

9. Ressuspend pellet (DNA) in $400 \mu \mathrm{l}$ of $1.2 \mathrm{M} \mathrm{NaCl}$.

10. Resuspended DNA was mixed with $400 \mu \mathrm{l}$ of chloroform

11. Centrifuge for $10 \mathrm{~min}$ at $12000 \mathrm{~g}$

12. Transffer aqueous phase in new tube and mix with a double volume of ice-cold absolute ethanol.

13. Incubate for $20 \mathrm{~min}$ at $20^{\circ} \mathrm{C}$ and then centrifuged for $15 \mathrm{~min}$ at $12000 \mathrm{~g}$.

14. Wash pellet $(2 \mathrm{x})$ with $500 \mu \mathrm{l}$ of $70 \%$ ethanol and air-dry

15. Dissolve in $100 \mu \mathrm{l}$ of nuclease-free water.

B. DNA extraction from milk using PrepFiler ${ }^{\mathrm{Th}}$ Forensic DNA Extraction Kit (according to manufacturer user guide, Applied Biosystem (2008)) 


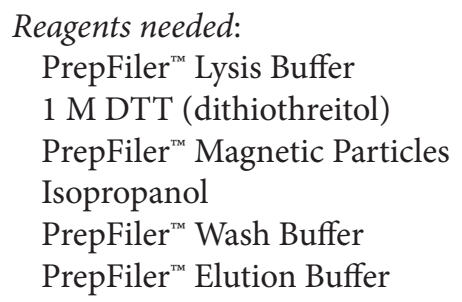

Procedure:

1. $40 \mu \mathrm{l}$ of sample was mixed with $300 \mu \mathrm{L}$ of PrepFiler ${ }^{\mathrm{Tm}}$ Lysis Buffer and $3 \mu$ Lof $1 \mathrm{M}$ DTT in $1.5 \mathrm{ml}$ tube and vortex for $5 \mathrm{~s}$

2. Incubate for $20 \mathrm{~min}$ at $70^{\circ} \mathrm{C}$ at $900 \mathrm{rpm}$.

3. Centrifuge for $2 \mathrm{~s}$ at $14000 \mathrm{rpm}$.

4. Using pippette, transffer solution into PrepFiler ${ }^{\mathrm{TM}}$ Filter Column that is placed into $1.5 \mathrm{~mL}$ PrepFiler ${ }^{\mathrm{TM}}$ Spin Tube

5. Centrifuge for $2 \mathrm{~min}$ at $14000 \mathrm{rpm}$.

6. Prepare magnetic particles by vortexing the PrepFiler ${ }^{\mathrm{Tm}}$ magnetic particles tube for 5 seconds at low speed and centrifuging for $2 \mathrm{~s}$ at $14000 \mathrm{rpm}$.

7. Disscard filter column and Pipette $15 \mu \mathrm{L}$ of magnetic particles into $1.5 \mathrm{~mL}$ PrepFiler ${ }^{\mathrm{TN}}$ Spin Tube.

8. Vortex spin tube at $1200 \mathrm{rpm}$ for 10 seconds and centrifuge for $2 \mathrm{~s}$ at $14000 \mathrm{rpm}$.

9. Add $180 \mu \mathrm{L}$ of isopropanol and vortex for $5 \mathrm{~s}$ at low speed .

10. Centrifuge for $2 \mathrm{~s}$ at $14000 \mathrm{rpm}$.

11. Mix at room temperature at $1000 \mathrm{rpm}$ for 10 minutes.

12. Vortex for $10 \mathrm{~s}$ at $14000 \mathrm{rpm}$.

13. Centrifuge for $2 \mathrm{~s}$ at $14000 \mathrm{rpm}$.

14. Place the tube in the magnetic stand and wait for 1-2 min until size of the pellet remain constant

15. Discard supernatant carfully (not to disturb DNA in pellet)

16. Wash the pellet $3 \mathrm{x}$ by pipetting $300 \mu \mathrm{L}$ of PrepFiler ${ }^{\mathrm{Tm}}$ Wash Buffer, vortexing $5 \mathrm{~s}$ at maximum speed and centrifuging for $2 \mathrm{~s}$ at $14000 \mathrm{~g}$. Supernatant is discard after each washing step

17. Place sample tube in the magnetic stand, open it and allow DNA to airdry for 7 to 10 minutes at room temperature.

18. Add $50 \mu \mathrm{L}$ of PrepFiler $^{\mathrm{Tm}}$ Elution Buffer and vortex for $5 \mathrm{~s}$ at maximum speed

19. Centrifuge for $2 \mathrm{~s}$ at $14000 \mathrm{rpm}$.

20. Incubate at $70^{\circ} \mathrm{C}$ at $900 \mathrm{rpm}$ for 5 minutes.

21. Vortex $5 \mathrm{~s}$ at maximum speed.

22. Centrifuge for $2 \mathrm{~s}$ at $14000 \mathrm{rpm}$.

23. Place the tube in the magnetic stand and wait until the size of the pellet stops increasing (at least 1 minute).

24. Pippete suppernatant (that contains sample DNA) into new $1.5 \mathrm{ml}$ tube. 
25. Additional step: if the eluted DNA extract is turbid, centruge for $5 \mathrm{~min}$ at $14000 \mathrm{rpm}$ and transffer supernatant into new tube.

\subsection{Extraction of RNA from food}

\subsubsection{Introduction:}

Basic steps in RNA extraction are the same as for DNA (homogenization, lysis, extraction and purification and elution). However, RNA is chemically more unstable compared to DNA, thus it is prone to degradation by RNAses (Lepinske et al. 1997) and sensitive to changes in temperature. Therefore, when working with RNA, it is crucial to prepare and maintain RNAses-free environment, by inhibiting enzymes with alcohol and low temperatures. Unlike DNAses, RNAses don't need addition of divalent ions for their activity. Further inhibition of endogenous RNAses is achieved by adding either 2-mercaptoethanol and/or guanidinium salts in extraction (lysis) buffer. 2-mercaptoethanol inhibits enzymatic action by breaking disulfide bonds in enzymes. Guanidinium salts also denature proteins, causing inhibition of RNAses.

Because most of the potential degradation of RNA by RNAses happens during sampling and homogenization, these two steps are crucial for obtaining non-degraded RNA of sufficient quantity (MacRae 2007). During sampling care must be taken to quickly place sample in liquid nitrogen in order to avoid degradation. Although it was thought that because of higher amount of RNA younger plant tissues are better choice, recent experiment (Johnson et al. 2012) showed that difference in amount of total RNA among older and younger tissues was only around $13 \%$. Also, not all plant tissues are equally metabolically active and thus don't contain same amount of RNA and/or same amount of inhibitors (such as phenolic compounds, among them especially tannins, polysaccharides, proteins, etc). During homogenization, there are a few possible obstacles in extracting RNA. Firstly, short time and/or not enough force during disruption will not release all RNA from cells in samples, thus leading to lower yield. Secondly, environment that is not exogenous RNAses-free will cause degradation of RNA during homogenization. Thirdly, during this step loss of sample might occur.

Extraction of RNA might be done either by commercial kits or by extraction with organic solvents. Of the latter, very popular is so-called Trizol extraction that uses guandinum thiocyanate, phenol and chloroform for extraction and purification of RNA. However, as every method it has its setbacks such as not giving good results with plant tissues that are rich in polysaccharides and phenolic compounds and it might be hard to dissolve the pellet (Rio et al. 2010). In most cases, extraction procedures are adjusted for a specific tissue or a purpose. Most of these modifications consider removal of specific inhibitors that would otherwise co-precipitate with RNA or bind with it. Among these inhibitors, 
polysaccharides and phenolic compounds are the most prominent. Polysaccharides can cause formation of slurry during resuspension (Dal Cin et al. 2005). Unlike with DNA extraction, enzymes like pectinase could not be used during extraction of RNA because of the risk of degradation (Dal Cin et al. 2005). Some protocols are adjusted not for a type of tissue but for a purpose. For example, in gene expression studies, it is necessary to modify a method to be quick, to work well with tissues with varying levels of inhibitors and to avoid steps that can affect yield (Vasanthaiah et al. 2008). Similar to DNA extraction, basic principle of RNA extraction is binding to silica-based column or membrane. Such binding can be based on negative charge of RNA or on differences in molecular masses between RNA and inhibitors in the extract.

During extraction of RNA by organic solvents, precipitation of pellet containing RNA is necessary. Resuspension of pellet could be a problematic step because it is known that presence of secondary metabolites could lower solubility of pellet after extraction involving guanidinium salts (Ghawana et al. 2011).

\subsubsection{Materials, Methods and Notes}

A. Extraction of total RNA from leaves and roots of Arabidopsis thaliana (according to RNeasy Mini Handbook Qiagen)

Reagents needed:

Buffer RLT

Buffer RW1

Buffer RPE

RNase-free water

\section{Protocol}

1. Homogenize $100 \mathrm{mg}$ of plant tissue (leaves or roots) in liquid nitrogen using mortar and pestle

2. Place grinded sample into $2 \mathrm{ml}$ tube

3. Add $450 \mu$ Buffer RLT (lysis buffer) and vortex at maximum speed

4. Transfer the lysate to a QIAshredder spin column that is already placed in a $2 \mathrm{ml}$ tube and centrifuge for $2 \mathrm{~min}$ at maximum speed.

5. Transfer the supernatant into new $2 \mathrm{ml}$ tube, without disturbing pellet

6. Add $500 \mu \mathrm{l}$ of absolute ethanol and mix by turning the tube

7. Transfer entire sample into the RNeasy spin column that is already placed in a $2 \mathrm{ml}$ tube. Close the lid.

8. Centrifuge for $15 \mathrm{~s}$ at $14000 \mathrm{rpm}$

9. After discarding flow-through, without changing tube, add $700 \mu \mathrm{l}$ Buffer RW1 to the RNeasy spin column. Close the lid.

10. Centrifuge for $15 \mathrm{~s}$ at $14000 \mathrm{rpm}$ 
11. After discarding flow-through, without changing tube, add $700 \mu \mathrm{l}$ Buffer RPE to the RNeasy spin column. Close the lid.

12. Centrifuge for $15 \mathrm{~s}$ at $14000 \mathrm{rpm}$

13. After discarding flow-through, without changing tube, add $700 \mu \mathrm{Buffer}$ RPE to the RNeasy spin column. Close the lid.

14. Centrifuge for $2 \mathrm{~min}$ at $14000 \mathrm{rpm}$

15. Place the RNeasy spin column in a new $1.5 \mathrm{ml}$ collection tube.

16. Add 30-50 $\mu \mathrm{l}$ RNase-free water directly to the spin column membrane.

17. Close the lid and centrifuge for $1 \mathrm{~min}$ at $14000 \mathrm{rpm}$. RNA remains in solution.

Notes: If the gene expression is going to be tested, two additional steps (elimination of genomic DNA and construction of cDNA) are necessary.

The QuantiTect Reverse Transcription kit combines these steps.

B. cDNA synthesis using QuantiTect Reverse Transcription kit (according to QuantiTect Reverse Transcription Handbook)

Reagents needed:

gDNA Wipeout buffer

RNAse- free water

Quantiscript reverse transcriptase

Quantiscript RT buffer

RT primer mix

\section{Protocol:}

1. While keeping tube with sample DNA on ice, add $2 \mu \mathrm{l}$ of wipeout buffer and with RNAse- free water adjuct volume, so that the total reaction volume is $14 \mu \mathrm{l}$

2. Incubate for $2 \mathrm{~min}$ at $42^{\circ} \mathrm{C}$ (during this time, genomic DNA eventualy present as contaminant is eliminated)

3. Place tube on ice and add $1 \mu \mathrm{l}$ of Quantiscript reverse transcriptase, $4 \mu \mathrm{l}$ of Quantiscript RT buffer and $1 \mu$ l of RT primer mix.

4. Incubate for $15 \mathrm{~min}$ at $42^{\circ} \mathrm{C}$ (during this step, cDNA is constructed)

5. Incubate for $3 \mathrm{~min}$ at $95^{\circ} \mathrm{C}$ (in order to denaturate reverse transcriptase).

\section{Real time PCR}

\subsection{Introduction}

At the moment real-time PCR is the only method that allows absolute quantification of nucleic acid. Its main application include: detection and quantification of pathogens (Kubista et al. 2006, Yang et al. 2004), detection of allergens in food (Parfundo et al. 2009), measurement of gene expression (Wong et al. 
2005), etc. Depending of purpose, it is possible to perform real time PCR from DNA and/or from RNA as a template.

Regardless whether starting material is RNA or DNA, the most critical steps in every real time procedure are obtaining good quality sample and choosing "good" primers. Good quality sample is high amount of purified, non-degraded nucleic acid. In case when different expression of gene is monitored, additional care must be taken in removing all traces of genomic DNA from mRNA. Otherwise, during synthesis of cDNA and further amplification, falsely high results might be expected. Of course, since as for "conventional" PCR integral part is amplification of target sequence, all inhibitors (lipids, proteins, carbohydrates, etc.) that affect success of "conventional" PCR will also influence reaction of real-time PCR.

Beside specificity, primers for real-time PCR must be stable (characterized by Tm values and GC content) and of certain size (in order to avoid miss-paring or loss in amplificability). Since there are different types of real-time PCR (such as duplex, multiplex, etc.) for each of these techniques there are additional conditions for primers (Shen et al. 2010). However, irrelevant of type of real-time PCR, analysis of sequence of forward and reverse primers must be done in order to avoid creation of secondary structure within primer itself or creation of so-called primer-dimmers. Primer-dimmers are created when hybridization happen not between primer and template but between forward or reverse primers with each other. There are several software (e.g. Primer 3, MPrimer, etc.) which give possibility to choose the best primer sequence based on the sequence of target gene. In such software characteristics of primers, such as melting temperature, GC content and possibility of production of secondary structures (including primer-dimmers) are given. Specificity of primers and eventual existence of primer-dimmers can be examined by melting curve analysis. In ideal situation, only one peak should be present for each curve. Also, location of peak for each curve must be the same, e.g. curves should overleap. As a control some of genes which have a constant expression (because of its involvement of basic metabolic pathways) are usually used. Such genes are called housekeeping genes. Also, to check efficiency of amplification, internal amplification control is used. Internal amplification control represents nontarget DNA fragment (of known concentration) that is added to the reaction and amplified in parallel with the target sequence.

There are two ways to monitor amplification process in real time. First approach uses SYBR Green chemistry. SYBR Green is fluorescent dye that intercalates with double stranded nucleic acid. Major disadvantage of SYBR Green approach is that it can bind to any double stranded nucleic acid and not just only to hybridization products between primer and target. Therefore, it will also bind to primer-dimmers. This binding decreases specificity of this method in comparison to TaqMan probe chemistry. TaqMan probe is a sequencespecific oligonucleotide probe that binds to a target in between forward and reverse primers. TaqMan probe has at each end attached a fluorescent dye-at 
5 ' end -fluorofore and at 3' end-quencher. Before PCR cycle fluorescence of fluorofore is "quenched" (inhibited) by quencher. During cycle, as DNA polymerase moves from 3' to 5 ' end, it encounters and hydrolyzes fluorofore from 5 ' end. Since emission of unbound fluorofore is no longer inhibited, fluorescence starts to increase. Sequence of TaqMan probe might be determined by same software in which it is possible to determine sequence of primers. However, due to chemistry of reaction, conditions for "good" TaqMan probe are different from those for primers. To ensure stability and specificity, Tm value and length for TaqMan probe are usually higher for those of primers. Since using guanine near the $5^{\prime}$ end of the TaqMan probe can quench fluorescence, it should be avoided. As for primers, sequence with consecutive stretches of the same base must be excluded (because it can affect hybridization efficiency due to formation of secondary structure).

Quantification is done by measuring fluorescence during cycles. Fluorescence is higher for higher concentration of product. Firstly, number of copies of DNA is insufficient for fluorescence to surpass threshold level. After few cycles, concentration of sample is sufficient for surpassing threshold level and fluorescence starts to increase exponentially. Because reaction efficiency is stable during exponential phase, a threshold level should be chosen so that it reflects data during this phase. After subtracting background from raw data, comparison of concentration of samples can be done.

\subsection{Materials, Metodes and Notes}

Procedure for Real time PCR (according to Getting Started Guide Applied Biosystems 7500/7500 Fast Real-Time PCR System Standard Curve Experiments)

A Preparation for experiment:

Two steps are necessary before measuring flourescence of sample and those are, of course, design of primers and prepartion of mix (layering the plate).

\section{B Primer design:}

Among on-line free based software for designing and analyzing samples, one of the most popular are Primer3 (Thornton et al. 2011) and Primer3Plus from NCBI (National Center for Biotechnology Information). However, designing and analyzing primers is also possible in software that are supplied with Real time PCR apparatus (with 7500/7500 Fast Real-Time PCR System, Primer Express v.3 software is supplied). Although procedure for preparing design for Real Time PCR using TaqMan probe involve additional step(s) for probe design, there are few parametars that are neccessary to adjust to get succesfull 
Real time PCR reaction. Those parametars are: primer lenght, melting temperature $\left(\mathrm{T}_{\mathrm{m}}\right)$, GC content, product size, 3 ' stability.

Length of the primer: if the primer is to short, due to the lack of specificity, it will not hybridize with template, while if it is too long hybridization will take too long and it will be hard to remove product. Optimal primer length is 18-24 base pairs (bp). Difference in primer pair length should be less than $3 \mathrm{bp}$.

Melting temperature $\left(\mathrm{T}_{\mathrm{m}}\right)$ is defined as temperature at which $50 \%$ of the primer is hybridized with its template. Again, too high $\mathrm{T}_{\mathrm{m}}$ will lead to secondary annealing, while to low $\mathrm{T}_{\mathrm{m}}$ will impede with hybridization. Optimal $\mathrm{T}_{\mathrm{m}}$ range is $57-65^{\circ} \mathrm{C}$. Difference in $\mathrm{T}_{\mathrm{m}}$ of forward and reverse primer should be less than $5^{\circ} \mathrm{C}$ (ideally $1^{\circ} \mathrm{C}$ ).

GC content is defined as the number of guanine and cytosine bases, expressed as a percentage of the total bases in primer. GC content is a measure of primer stability (stability is expressed through $\Delta G$ value) and should be $40-60 \%$. In addition to this, number of guanine and cytosine within the last five bases from the $3^{\prime}$ end of primers is called GC clamp. GC clamp value should be less than 3 , because although $\mathrm{G}$ and $\mathrm{C}$ residues at $3^{\prime}$ end will enhance specific binding to template, such sequence will give amplicons of bigger sizes.

Size of product- fluorescence during $\mathrm{SYBR}^{\oplus}$ Green detection will be more intense if product is longer. Ideal amplicon size is between 80 and $150 \mathrm{bp}$. Shorter amplicons are amplified more efficiently than longer ones.

$3^{\prime}$ stability is expressed as maximum $\Delta G$ value of the last five bases at $3^{\prime}$ end of the primers. Higher 3 ' stability means improved efficiency of the primers. Also, some factors, as for example concentration of divalent ions, might need to be changed (usually SYBR ${ }^{\circledR}$ Green buffer mixes contain 3 to $6 \mathrm{mM}$ of $\mathrm{Mg}^{2+}$ ). During primer synthesis it is essential to check number of repeats and runs, since higher number of repeats and/or runs will lead to miss-priming or/and formation of primer secondary structures. Repeats are repeated sequences of dinucleotide (maximum number of repeats should be 4). Runs are defined as single nucleotide sequence repeats and their preferred maximum number is 3-4 bp. Also, when working with TaqMan probe, it is necessary to adjust $\mathrm{T}_{\mathrm{m}}$ of the probe to around $10^{\circ} \mathrm{C}$ higher than $\mathrm{T}_{\mathrm{m}}$ of primers (because the minor groove binding will increase $\mathrm{T}_{\mathrm{m}}$ of the probe) and size should be less than $30 \mathrm{bp}$ (not to affect specificity). Also, guanine residue at $5^{\prime}$ end should be avoided because it can quench fluorescence.

Analysis of primers can be done in software like Vector NTI and MP primer. In this software there is an option to check for possibility of formation of secondary structure, like hairpins and/or primer-dimmers.

\section{Steps}

1. Finding and coping the sequence in FASTA Format NCBI website (http:// www.ncbi.nlm.nih.gov/guide/) $\rightarrow$ nucleotide database (from dropdown menu) $\rightarrow$ in search box enter gene code $\rightarrow$ search $\rightarrow$ display settings $\rightarrow$ FASTA $\rightarrow$ apply Copy FASTA sequence into new word document. 
2. NCBI website $\rightarrow$ tools $\rightarrow$ BLAST $\rightarrow$ primer BLAST or alternatively go to Primer3 website (http://bioinfo.ut.ee/primer3-0.4.0/)

3. Copy sequence from word file in PCR template (or in sequence ID in Primer3)

4. Either use your own primers or give a range for forward and reverse primers (in primer 3 check boxes: Pick left primer, or use left primer below and Pick right primer, or use right primer below; if you are working with TaqMan also check box Pick hybridization probe)

5. In exon/intron selection, cut the intron part (In primer3 $\rightarrow$ excluded regions)

6. Change primer parameters or leave it default (In Primer3 $\rightarrow$ General primer picking conditions)

7. Click get (pick) primers

\section{Layering the plate}

Microtitar plate with 96 wells is used. Beside samples, 2 internal standards and blanc probe should also be loaded in wells. Blanc (negative) probe contains all that is in sample, except cDNA. Internal standards are so-called housekeeping gens that code for proteins that are expressed in all cells, since they are involved in basic cellular processes (e.g. gen for GAPDH). In sample wells load: $25 \mu \mathrm{l} 2 \mathrm{x}$ SYBER Green PCR Master Mix $+6.2 \mu \mathrm{l}$ forward primers $+6.2 \mu \mathrm{l}$ reverse primers $+6.2 \mu \mathrm{l}$ cDNA sample $+6.4 \mu \mathrm{l}$ RNAse-free $\mathrm{H}_{2} \mathrm{O}$. However, concentration of water, primers and sample is variable and should be optimized for particular reaction.

\section{Run}

Cover the plate with transparent foil and centrifuge for few seconds (Centrifugation is done in order to avoid air bubbles).

Load the plate in plate holder and align.

By pushing, close the tray door.

In Setup page, choose run option.

In Run Method, it is possible to select number of cycles and change run parameters. Default run settings:

1. pre-PCR phase $-60^{\circ} \mathrm{C}, 30$ s (elongation)

2. holding stage $-95^{\circ} \mathrm{C}, 10 \mathrm{~min}$ (activation of Hot-Start DNA polymerase)

3. cycling stage $-92^{\circ} \mathrm{C}, 15 \mathrm{~s}$ (melting of DNA); followed by $90 \mathrm{~s}$ at $60^{\circ} \mathrm{C}$ (annealing of primers to templates and in the case of TaqMan Real time PCR, also the probe).

Click start run button.

Note: Run can be monitored by selecting amplification plot and choosing option of view plate layout. 


\section{Acknowledgments}

Authors are grateful to AREA project (FP7-REGPOT-0212-2013 -I) and University of Parma, Department of Life Sciencies for providing training and expertise.

\section{References}

Agrimonti, C., Vietina, M. Pafundo, S., \& Marmiroli, N. (2011).The use of food genomics to ensure the traceability of olive oil. Trends in food science and technology, 22, 237-244. DOI: https://doi.org/10.1016/j.tifs.2011.02.002

Berdal, K.G., \& Holst-Jensen, A. (2001). Roundup Ready soybean event-specific real-time quantitative PCR assay and estimation of the practical detection and quantification limits in GMO analyses European Food Research and Technology, 213, 432-438. DOI: https://doi.org/10.1007/s002170100403

Colatat, M. Effect of Homogenization Method on DNA Yield and Fragment Size. Retrieved from http://opsdiagnostics.com/applications/nucleicacids/ homogdnacompare.htm

Corbisier, P., Broothaerts, W., Gioria, S., Schimmel, H., Burns, M., \& Baoutina, A. (2007). Toward metrological traceability for DNA fragment ratios in GM quantification. 1. Effect of DNA extraction methods on the quantitative determination of Bt176 corn by Real-Time PCR. Journal of Agriculture and Food Chemistry, 55, 3249-3257. DOI: https://doi.org/10.1021/jf0629311

Cserháti, T., Forgács, E., Deyl, Z., \& Miksik, I. (2005). Chromatography in authenticity and traceability tests of vegetable oils and dairy products: a review. Biomedical Chromatography, 19, 183-190. DOI: https://doi. org $/ 10.1002 /$ bmc.486

Dal Cin, V., Danesin, V., Rizzini, M. F., \& Ramina, A. (2005). RNA Extraction From Plant Tissues. The Use of Calcium to Precipitate Contaminating Pectic Sugars. Molecular biotechnology, 31: 113-119. DOI: https://doi. org/10.1385/MB:31:2:113

Galimberti, A., De Mattia, F., Losa, A., Bruni, I., Federici, S., Casiraghi, M., Martellos, S., \& Labra, M. (2013). DNA barcoding as a new tool for food traceability. Food research international, 50, 55-63. DOI: https://doi. org/10.1016/j.foodres.2012.09.036

Ganopoulos, I., Argiriou, A., \& Tsaftaris, A. (2011). Microsatellite high resolution melting (SSR-HRM) analysis for authenticity testing of protected designation of origin (PDO) sweet cherry products. Food Control, 22, 532-541. DOI: https://doi.org/10.1016/j.foodcont.2010.09.040

Gasparic, M. B., Tengs, T., La Paz, J. L., Holst-Jensen, A., Pla, M., Esteve, T., Zel, J., \& Gruden, K. (2010). Comparison of nine different real-time PCR chemistries for qualitative and quantitative applications in GMO detection. Analitical and Bioanaltical Chemistry, 396, 2023-2029. DOI: https://doi. org/10.1007/s00216-009-3418-0 
Getting Started Guide Applied Biosystems 7500/7500 Fast Real-Time PCR System Standard Curve Experiments (6), Part Number 4387779 Rev. C 06/2010. Retrieved from http://www3.appliedbiosystems.com/cms/groups/ mcb_support/documents/generaldocuments/cms_050329.pdf

Ghawana, S., Paul, A., Kumar, H., Kumar., A., Singh, H., Bhardwaj, P.A., Rani, A., Singh, S.R., Raizada, J., Singh, K., \& Kumar, S. (2011). An RNA isolation system for plant tissues rich in secondary metabolites. BMC Research Notes, 4, 85. DOI: https://doi.org/10.1186/1756-0500-4-85

Gryson, N. (2010). Effect of food processing on plant DNA degradation and PCR-based GMO analysis: a review. Analitical and bioanalitical chemistry, 396, 2003-2022. DOI: https://doi.org/10.1007/s00216-009-3343-2

Hrncirova, Z., Bergerova, E., \& Siekel, P. (2008). Effects of technological treatment on DNA degradation in selected food matrices of plant origin. Journal of Food and Nutrition Research, 47(1), 23-28.

Johnson, T. J. M., Carpenter, J. E., Tian, Z., Bruskiewich, R., Burris, N.J., Carrigan, C., Chase, W.M., Neil, D.C., Covshoff, S., de Pamphilis W. C., Edger, P.P., Goh, F., Graham, S., Greiner, S., Hibberd, J. M., Jordon Thaden I., Kutchan, T. M., Leebens-Mack, J., Melkonian, M., Miles, N., Myburg, H., Pires, J.M., Ralph, P., Rolf, M., Soltis, D., Soltis, P., Stevenson, D., Stewart, C. N. J., Thomsen, J. M. C., Villarreal, J. C., Wu, X., Zhang, Y., Sage, R. F., Surek, B., Deyholos, M. K., \& KaShu Wong, G. (2012). Evaluating Methods for Isolating Total RNA and Predicting the Success of Sequencing Phylogenetically Diverse Plant Transcriptomes. PLoS ONE 7(11), e50226, DOI: https://doi.org/10.1371/journal.pone.0050226

Kim, J. H., Kim, S. Y., Lee, H., Kim, Y. R. \& Kim, H. Y. (2010). An event-specific DNA microarray to identify genetically modified organisms in processed foods. Journal of agricultural and food chemistry, 58(10), 6018-6026. DOI: https://doi.org/10.1021/jf100351x

Kubista M., Andrade J. M., Bengtsson M., Forootan A., Jonák J., Lind K., Sindelka R., Sjöback R., Sjögreen B., Strömbom L., Ståhlberg A., \& Zoric N (2006). The real-time polymerase chain reaction. Molecular Aspects of Medicine, 27, 95-125. DOI: https://doi.org/10.1016/j.mam.2005.12.007

Lepinske, M. (1997). Tips for Working with RNA and Troubleshooting Downstream Applications. Promega Notes Magazine, 63, 17-22.

Lincoln, J. E., Richael, C., Overduin, B., Smith, K., Bostock, R., \& Gilchrist, D. G. (2002). Expression of the antiapoptotic baculovirus p35 gene in tomato blocks programmed cell death and provides broad-spectrum resistance to disease. Proceedings of National Acadamy of Scienies 99(23), 15217-15221. DOI: https://doi.org/10.1073/pnas.232579799

Luykx, M. A. M. D., \& van Ruth, M. S. D. (2008). An overview of analytical methods for determining the geographical origin of food products. Food Chemistry, 107, 897-911. DOI: https://doi.org/10.1016/j.foodchem.2007.09.038

MacRae, E. (2007) Extraction of Plant RNA. In E. Hilario, \& J. Mackay (Eds.), Methods in Molecular Biology (pp. 15-24). Protocols for Nucleic Acid Analysis by Nonradioactive Probes, 2nd Edition, Humana Press, Totowa. 
Marmiroli, N. Peano, C., \& Maestri, E. (2003). Advanced PCR techniques in identifying food components. In M Lees (Ed.), Food authenticity and traceability (pp. 1-33). CRC Press, Boca Raton Boston New York Washington, Woodhead Publishing Ltd. DOI: https://doi.org/10.1533/9781855737181.1.3

Mesnage, R., Clair, E., Gress, S., Then, C., Székács, A., \& Séralini, G.E. (2013). Cytotoxicity on human cells of CrylAb and CrylAc Bt insecticidal toxins alone or with a glyphosate-based herbicide. Journal of Applied Toxicology, 33(7), 695-699. DOI: https://doi.org/10.1002/jat.2712

Miller, D.N., Bryant, J. E., Madsen, E.L., \& Ghiorse, W. C (1999). Evaluation and optimization of DNA extraction and purification procedures for soil and sediment samples. Applied and environmental microbiology, 65(11), 4715-4724.

Ogasawara, T., Arakawa, F., Akiyama, H., Goda, Y., \& Ozeki, Y. (2003). Fragmentation of DNAs of processed foods made from genetically modified soybeans. Japanese Journal of Food Chemistry, 10(3),155-160. DOI: https:// doi.org/10.18891/jjfcs.10.3_155

Parfundo S., Gulli M., \& Marmiroli N. (2009). SYBR-Green Real-time PCR to detect almond traces in processed food. Food Chemistry, 116, 811-815. DOI: https://doi.org/10.1016/j.foodchem.2009.03.040

Pirondini, A., Bonas, U., Maestri, E., Visioli, G., Marmiroli, M., \& Marmiroli, N. (2010). Yield and amplificability of different DNA extraction procedures for traceabilityin the dairy food chain. Food Control, 21, 663-668. DOI: https://doi.org/10.1016/j.foodcont.2009.10.004

Primrose, S., Woolfe, M., \& Rollinson, S. (2010). Food forensics: methods for determining the authenticity of foodstuffs. Trends in food science and technology, 21, 582-590. DOI: https://doi.org/10.1016/j.tifs.2010.09.006

QuatiTect Reverse Transcription Handbook, Qiagen, 03/2009

Randhawa, G. J., Singh, M., \& Sood, P. (2016). DNA-based methods for detection of genetically modified events in food and supply chain. Current science, 110(6), 1000-1009. DOI: https://doi.org/10.18520/cs/ v110/i6/1000-1009

Rio, D. C., Ares, M. Jr., Hannon, G. J., \& Nilsen, T. W. (2010). Purification of RNA using TRIzol (TRI reagent). Cold Spring Harbor Protocols 6, RNeasy Mini Handbook, Qiagen, 06/2012. DOI: https://doi.org/10.1101/pdb.prot5439

Shen, Z., Qu, W., Wang, W., Lu, Y., Wu, Y., Li, Z., Hang, X., Zhao, D., Zhang, C. \& Wang, X. (2010). MPprimer: a program for reliable multiplex PCR primer design. BMC Bioinformatics, 11, 143-149. DOI: https://doi. org/10.1186/1471-2105-11-143

Tengel, C., Schüßler, P., Setzke, E., Balles, J., \& Sprenger-Haußels, M. (2001). PCR-based detection of genetically modified soybean and maize in raw and highly processed foodstuffs. BioTechniques, 31, 426-429. DOI: https://doi. org/10.2144/01312pf01

Terry, C., Harris, N. \& Parkes, H. (2002). Detection of genetically modified crops and their derivatives: critical steps in sample preparation and extraction. Journal of AOAC International, 85(3), 768-774. 
Thornton, B. \& Basu, C. (2011). Real-time PCR (qPCR) primer design using free online software. Biochemistry and molecular biology education, 39(2), 145-154. DOI: https://doi.org/10.1002/bmb.20461

Tung Nguyen, C. T., Son, R., Raha, A. R., Lai, O. M., \& Clemente Michael, W. V. L. (2009). Comparison of DNA extraction efficiencies using various methods for the detection of genetically modified organisms (GMOs). International Food Research Journal, 16, 21-30.

Turci, M., Sardaro, M., Visioli, G., Maestri, E., Marmiroli, M., \& Marmiroli, N. (2010) Evaluation of DNA extraction procedures for traceability of various tomato products. Food Control, 21, 143-149. DOI: https://doi.org/10.1016/j. foodcont.2009.04.012.

User guide PrepFiler ${ }^{\mathrm{Tm}}$ Forensic DNA Extraction Kit. Applied Biosystem, Part Number 4390932 Rev. B 11/2008, 2008. Retrieved from http://www3. appliedbiosystems.com/cms/groups/applied_markets_support/documents/generaldocuments/cms_053966.pdf

Van den Bulcke, M., Lievens, A., Barbau-Piednoir, E., MbongoloMbella, G., Roosens, N., Sneyers, M., \& Casi, A.L. (2010). A theoretical introduction to "combinatory SYBRGreen qPCR screening", a matrix-based approach for the detection of materials derived from genetically modified plants. Analitical and bioanalitical chemistry, 396(6), 2113-23. DOI: https:// doi.org/10.1007/s00216-009-3286-7

Vasanthaiah, K. N. H., Katam, R., \& Sheikh, B. M. (2008). Efficient protocol for isolation of functional RNA from different grape tissue rich in polyphenols and polysaccharides for gene expression studies. Electronic Journal of Biotechnology, 11(3), DOI: https://doi.org/10.2225/vol11-issue3-fulltext-5

Vinci, G., Preti, R., Tieri, A., \& Vieri, S. (2013). Authenticity and quality of animal origin food investigated by stable-isotope ratio analysis. Journal of Science of Food and Agriculture, 93(3),439-48. DOI: https://doi.org/10.1002/ jsfa. 5970

Wen-Tao, X., Wei-Bin, B., Yun-Bo, L., Yan-Fang, Y., \& Kun-Lun, H. (2009). Research progress in techniques for detecting genetically modified organisms. Chinese Journal of Agricultural Biotechnology, 6(1), 1-9. DOI: https:// doi.org/10.1017/S1479236209002575

Wilson, G. I. (1997). Inhibition and facilitation of nucleic acid amplification. Applied and environmental microbiology, 63(10), 3741-3751. DOI: https:// doi.org/0099-2240/97/\$04.0010

Wong, M. L. \& Medrano, J. F. (2005). Real-time PCR for mRNA quantitation. BioTechniques, 39,75-85. DOI: https://doi.org/10.2144/05391RV01

Woodcock, T., Fagan, C., O’Donnell, C., \& Downey, G. (2008). Application of near and mid-infrared spectroscopy to determine cheese quality and authenticity. Food Bioprocess Technology, 1, 117-129. DOI: https://doi. org/10.1007/s11947-007-0033-y

Yang, S., Rothman, R. E. (2004). PCR-based diagnostics for infectious diseases: uses, limitations, and future applications in acute-care settings. Infectious Diseases, 4, 337-348. DOI: https://doi.org/10.1016/S1473-3099(04)01044-8 
